\title{
EFFECTS OF DOMESTIC LIVESTOCK AND NATIVE WILDLIFE GRAZING IN Grand Teton National Park
}

\author{
MichaEl A. SMITH $\diamond$ JERROLD L. DODD $\diamond$ PAUl MEIMAN \\ RANGE MANAGEMENT DEPARTMENT $\bullet$ UNIVERSITY OF WYOMING \\ LARAMIE
}

\section{$\checkmark \quad$ INTRODUCTION}

The Snake River plains and foothill areas of Jackson Hole have been grazed by domestic livestock since settlement of the area. Wildlife populations, including elk, mule deer, and antelope have historically used and continue to use the area. Moose are currently relatively abundant and a small herd of bison have been introduced. Currently, livestock use part of the area contained in Grand Teton National Park either as a concession or due to authorization by Park enabling legislation. Park managers need information concerning the effects of grazing by large ungulates on vegetation resources to assist in effectively managing grazing to service forage needs and achieve desired plant community goals.

\section{- OJECTIVES} as follows:

The objectives of this research are summarized

1) Determine kind and location of important potential natural plant communities (PNC's) within a study area largely defined by areas of current use by livestock, east of the Snake River, and adjacent comparable areas used only by wildlife, west of the river.

2) Compare current vegetation composition on representative sites used by livestock and wildlife with potential composition for the same sites with an emphasis on comparisons of livestock and wildlife effects.

3) Estimate forage utilization on key sites and map. utilization patterns.

4) Establish permanent vegetation trend monitoring transects.

5) Provide grazing management recommendations to the Park Service to assist them in reaching their vegetation management goals.

6) Assess impacts of herbivory on density of woody plant species along the Snake River.

\section{- STUdY AREA}

The study area is in Grand Teton National Park and primarily includes areas along and west of the Snake River used by wildlife and areas of similar vegetation east of the river where livestock are a predominant or important user. Livestock areas include the Cunningham Cabin pasture, Triangle $\mathrm{X}$ guest ranch horse pasture, the Uhl Draw/Elk Ranch Reservoir area, Blacktail Butte pasture, and Antelope Flats to a lesser extent. 


\section{- MethodS}

Establishment of field sites for data collection began in June of 1991. Specific areas had been examined in August 1990 with respect to potential for high use by grazing animals and need for detailed vegetation analysis and monitoring. In these areas specific selected sites included: 1) Upland plains west of the Snake River, grazed only by wildlife. Sites characterized by sagebrush-grass vegetation were located in the Potholes area (sec 23 R115W T44N) and Cow Lake (sec 32 R114W T44N) area. 2) Floodplains (Cottonwood dominated lowlands and wetlands characterized by willow/sedge communities) west of the Snake River, grazed only by wildlife. Two sites were located across from the Triangle $\mathrm{X}$ horse pasture (sec 7 R114W T44N). 3) Elk Ranch Reservoir area, grazed predominantly by cattle in summer and by wildlife. Sites were located in upland (sec 12 R114W T44N) and lowland (sec 1\&2 R114W $\mathrm{T} 44 \mathrm{~N})$ sagebrush-grass vegetation, and in a subirrigated graminoid community (sec 6 R113W T44N). 4) Large pasture east of the Snake River and between the Cunningham Cabin and the river, grazed by both wildlife and livestock in summer. A site was located in a marginally irrigated graminoid vegetation type (sec R114W T44N). 5) Floodplains east of the Snake River in the Triangle $\mathrm{X}$ horse pasture, grazed by horses in summer and wildlife. Sites were located in cottonwood lowlands and subirrigated willow/graminoid habitats (sec 24 R115W T44N). 6) Antelope Flats, the upland plain east of the Snake River, minimally grazed by cattle during trailing to summer pasture and wildlife. A site was located in sagebrush-grass vegetation ( $\sec 2$ R115W T43N). 7) Blacktail Butte pasture, south of the Butte, grazed by cattle in early summer and wildlife. A site was located in sagebrush-grass vegetation (sec 7 R115W T42N).

The standard monitoring program installed on each of the 12 sites consisted of a trend transect with $20, .25 \mathrm{~m}^{2}$, permanently marked quadrats and 5,1 $\mathrm{m}^{2}$, movable cages. An additional 20 temporary quadrats were located parallel to the trend transect when sampling was conducted. Additionally, sites in cottonwood and willow communities had 3 utilization transects with 100 marked twigs of woody plants.

Permanent quadrat locations on trend transects, inside cages, and temporary quadrat locations were sampled in July and August 1991 and 1992, near peak standing crop, with a $.25 \mathrm{~m}^{2}$ nested frequency quadrat frame (US Forest Service Region 4 Range Analysis Handbook). Nested frequency scores were recorded for every species of herbaceous and low shrub vegetation. Standing crop of major species and functional groups, i.e. forbs, was estimated. Onehalf of the temporary and all caged quadrats were harvested with major species or functional groups estimated bagged separately, dried, and weighed. Synthesis of these data include determining the relationship between estimated and harvested weights and adjustment of estimated weights by application of regression coefficients. Percent composition by weight of species and groups will be calculated. Relationships of composition to frequency scores will be examined. Comparisons of site frequency scores and composition by weight to available estimates of potential plant community (PNC) scores and composition (from USDA Soil Conservation Service technical guides and Forest Service records) will be made to assess ecological condition.

The utilization study started by the Botswannan student was abandoned due to his changing to another program. Consequently, we refocused our efforts on 2 species, willow and cottonwood with new transects logistically more compatible with our work force. These utilization transects (12 total, 3 each willow and cottonwood, each side of the river) were established in August by marking twigs with colored wire and recording length of twigs of willow or cottonwood. Any browsing as of August was noted. Twig lengths will be measured again in November 1992 and May 1993 to determine fall and winter utilization respectively of each species for each transect. Utilization will be based on difference in twig lengths over each period of measurement.

Density of major trees and shrubs in floodplain/riparian areas was determined again in 1992 to assess relatively large scale use pattern effects on these types of habitats. The sample plot location procedure this year provided for equal representation of the flood plain on each side of the river. Predominant grazing animal use west of the Snake River is by wildlife including bison and elk in summer and large concentrations of elk in late fall; the Triangle $\mathrm{X}$ pasture is used by horses and wildlife in summer and wildlife in winter while other areas east of the river are used by wintering moose. Hunting may limit elk concentrations east of the river during fall. All areas have moose grazing in winter. 
Occurrence of all size classes of a species could indicate reproduction is occurring while a restricted number of one age class or substantial differences in numbers of plants might suggest some limitation. Sampling consisted of counting the number of plants of each species of tree or shrub in 3 size classes $(1=$ $<1.5 \mathrm{~m}, 2=1.5-3 \mathrm{~m}, 3=>3 \mathrm{~m}$ ) in a 20 by 20 $\mathrm{m}$ plot. Sampling was stratified into cottonwood communities and willow dominated communities. In the floodplain east and west of the Snake River, sample plots were located at about $0.4 \mathrm{~m}$ (1/4 mile) intervals if communities were present, from near the old Bar-BC Ranch north to near RKO Road, a distance of about $16 \mathrm{~km}$. At each point the nearest stand of cottonwood and willow community was sampled.

Mapping of utilization patterns was conducted in late August to assist in broadening the area of inference associated with individual study sites. Comments in this regard will primarily address differences in use of different habitats rather than spatial differences as customarily associated with mapping, due to the biggest differences typically occurring between habitats rather than between different places in an area with the same habitat.

\section{$\checkmark$ RESULTS}

Data summary for this year is underway. A summary of the tree and shrub density without statistical analysis is available and presented below (Table 1). Programming of the productivity summarization software program has been completed and data entry is well underway.

Forest Service records in Jackson were searched without success for plant community (PNC) descriptions that would be useful for our study area. The absence of PNC descriptions based on nested frequency means that these data will only be useful for trends and that Soil Conservation Service (SCS) guidelines based on biomass will be used to assess ecological condition of sites. SCS personnel have visited the study sites and will return next summer with a soil scientist to verify that appropriate PNC descriptions will be used in assessing ecological descriptions. Nested frequency monitoring if continued in the future may be useful for indicating whether some type of change is occurring in a species. However, additional data from some other plant abundance measure, in this case the biomass measurement, must be available to indicate what type of change is occurring.

Woody plant densities were sampled to test the hypothesis that more fall and winter grazing by elk and moose west as compared to east of the Snake River was limiting the recruitment of plants into larger size classes. Hunting may limit fall elk use east of the river. Circumstantial evidence of this occurrence would be a reduction, west of the river in density of one or more of the smaller size classes. Ultimately taller size classes would also be reduced. The palatable shrubs, water birch, silverberry, russet buffaloberry, and willow, appear to be more abundant east of the river (Table 1). Engelmann spruce appears to be increasing in all areas but more so east of the river as indicated by the presence of all age classes, suggesting the probable replacement of deciduous tree and shrub communities by spruce.

The reconnaissance to map utilization patterns generally indicated that through late August utilization levels at the sampling sites was representative of the area where the site was located. Summer utilization of vegetation in the sagebrush-grass community of the Potholes and Cow Lake areas was low. Elk using the area appeared to have made more use of edges of timbered areas particularly where aspen occurred. Lake borders in the Potholes area had heavy use of subirrigated vegetation. A wet meadow near Cow Lake was found that had very little utilization of herbaceous material suggesting that grazing in that area occurs in fall and winter, if at all. Antelope were making heavy use of ephemeral vegetation in the bottom of Cow Lake as the water receded. Floodplain herbaceous vegetation west of the Snake River was used at moderate levels. Highest use occurred in subirrigated perimeters of wet areas dominated by Kentucky bluegrass and clover. In the Cunningham pasture, subirrigated areas dominated by Kentucky bluegrass and clover were heavily used while adjacent wet areas characterized by tall sedges received little use. The Triangle $X$ pasture had received light to moderate use overall. Few areas of intensive use were evident. Grazing in the Uhl Hill pasture by cattle was concentrated in the irrigated areas and adjacent lowland sagebrush-grass area downstream from the reservoir. Herbage in the 


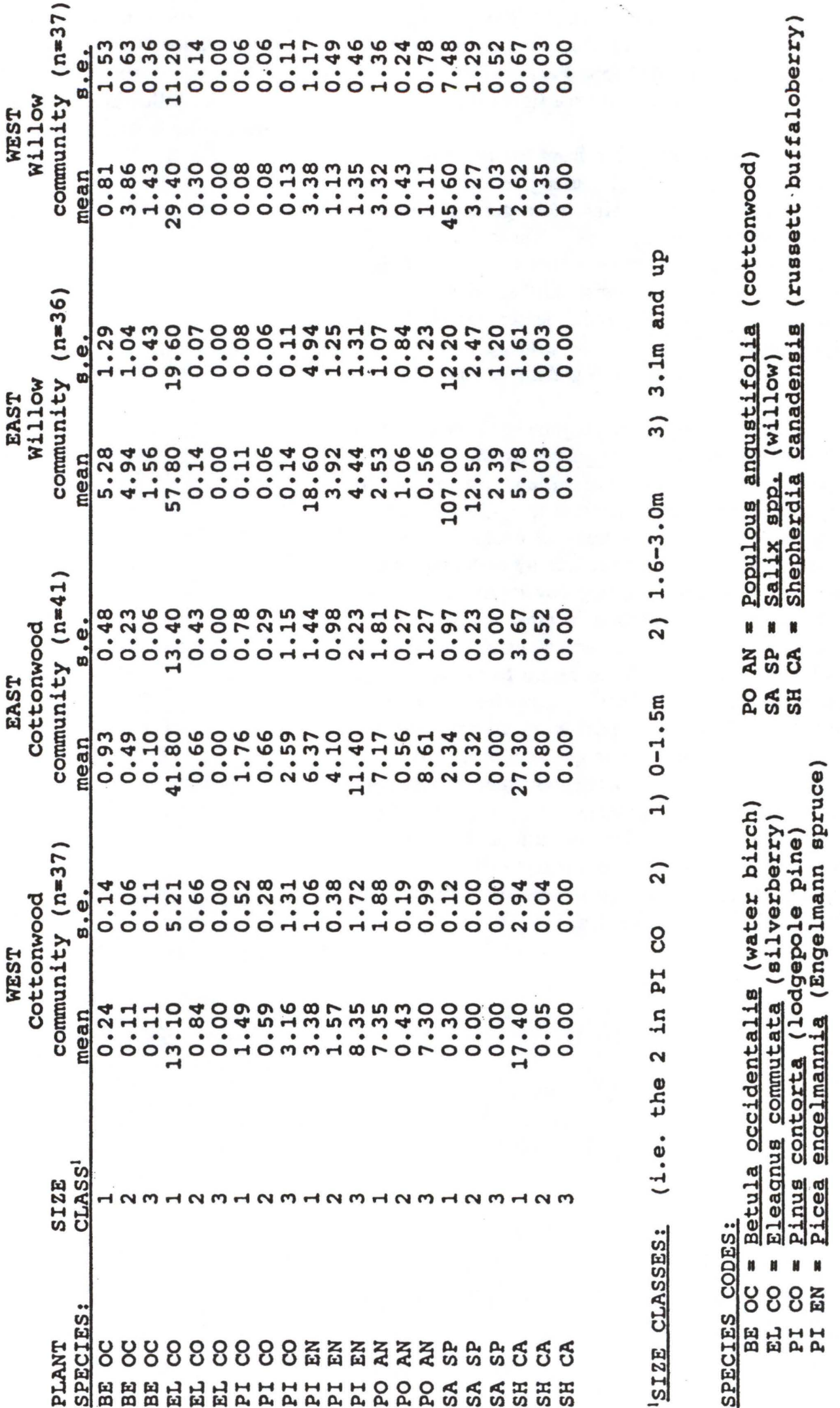


subirrigated zone along Uhl Draw had been used heavily while the wetter soil zone near the channel received only moderate use. Little grazing was evident on the hills surrounding the reservoir despite abundant forages. Antelope Flats and the Blacktail Butte pasture had received very light use.

A general conclusion from the reconnaissance was that subirrigated, bluegrass/clover plant communities, wherever significant grazing pressure occurs, form a grazing lawn. These lawns, while generally considered to be a low seral community, are very stable and resist further change from grazing. They would provide lesser quantity but a higher quality forage for the grazing animal, thus their continued attraction to grazing animals.

The need for improved grazing management in the Uhl Hill pasture is suggested by the low use of uplands and concentration of cattle grazing along $\mathrm{Uhl}$ Draw riparian zones. Several activities should be considered. Sagebrush burning could be used to increase the availability and quality of forages away from riparian areas. Spring developments or other water source augmentation in areas away from the riparian zone and the reservoir would reduce the continual need for cattle to return to the stream or reservoir for water. Increased herding of animals would minimize time spent near streams and the reservoir. Intensified management of the irrigated pastures such as crossfencing and water management could reduce the grazing time required from rangeland forages. Greater use and intensified management of pastures south and east of Blacktail Butte could also reduce the reliance on forages from the rangeland along Uhl Draw.
There appears to be little of the summer season 1992 results that vary from the results of the 1991 sampling season. Utilization patterns and vegetation composition appear to be similar. The general differences in shrub density between east and west of the river following the change in sampling locations are similar to differences observed last year. 